DEMOGRAPHIC RESEARCH

VOLUME 42, ARTICLE 37, PAGES 1057-1096

PUBLISHED 11 JUNE 2020

http://www.demographic-research.org/Volumes/Vol42/37/

DOI: $\quad$ 10.4054/DemRes.2020.42.37

Research Article

Mobile phones, digital inequality, and fertility:

Longitudinal evidence from Malawi

\author{
Francesco C. Billari
}

Valentina Rotondi

Jenny Trinitapoli

(C) 2020 Billari, Rotondi \& Trinitapoli.

This open-access work is published under the terms of the Creative Commons Attribution 3.0 Germany (CC BY 3.0 DE), which permits use, reproduction, and distribution in any medium, provided the original author(s) and source are given credit.

See https://creativecommons.org/licenses/by/3.0/de/legalcode 


\section{Contents}

$\begin{array}{llr}1 & \text { Introduction } & 1058\end{array}$

$2 \quad$ Background and context $\quad 1059$

$\begin{array}{lll}2.1 & \text { Conceptual background } & 1059\end{array}$

$\begin{array}{lll}2.2 & \text { Study context } & 1061\end{array}$

3 Data, measures, and methods $\quad 1062$

$3.1 \quad$ Key fertility measures $\quad 1062$

3.2 Key measures of mobile phone ownership 1063

3.3 Micro-level analogs to the proximate determinants of fertility 1063

3.4 Time-varying control variables 1063

$\begin{array}{lll}3.5 & \text { Analytic approach } & 1064\end{array}$

3.5.1 Cox proportional hazard models 1066

$\begin{array}{lll}\text { 3.5.2 TLT-2 (2015) cross-section } & 1067\end{array}$

$4 \quad$ Results $\quad 1067$

4.1 Balaka's digital divide: Mobile phone ownership, 2009-2015 1067

4.2 Mobile phone ownership and fertility: A bivariate view 1071

4.3 Mobile phone ownership and fertility: Panel data estimates 1072

4.4 Phones and family formation $\quad 1074$

4.5 From phone ownership to phone use 1077

$\begin{array}{lll}5 & \text { Discussion and conclusions } & 1081\end{array}$

$6 \quad$ Acknowledgments $\quad 1084$

$\begin{array}{lr}\text { References } & 1085\end{array}$

$\begin{array}{lr}\text { Appendix A } & 1090\end{array}$ 


\title{
Mobile phones, digital inequality, and fertility: Longitudinal evidence from Malawi
}

\author{
Francesco C. Billari ${ }^{1}$ \\ Valentina Rotondi ${ }^{2}$ \\ Jenny Trinitapoli ${ }^{3}$
}

\begin{abstract}
BACKGROUND

In this paper, we introduce the digital revolution as a potential ingredient of sub-Saharan Africa's fertility transition.

\section{OBJECTIVE}

We focus on the relationship between mobile phone ownership and childbearing in southern Malawi, showing that mobile phone acquisition is associated with reductions in ideal family size and lower overall parity among phone-owning women compared to their phone-less counterparts.
\end{abstract}

\section{METHODS}

We use nine waves of data from the Tsogolo la Thanzi (TLT) longitudinal study conducted in Balaka, Malawi, between 2009 and 2015.

\section{RESULTS}

Fixed-effects panel data models shows that mobile phone ownership is associated with smaller ideal family size and lower parity during the study period. Cox proportional hazard models suggest that mobile phones are not fundamentally associated with the timing of women's first steps in family formation but rather with fertility trajectories on a longer time-horizon through child spacing. Furthermore, complementary cross-sectional analyses from a later survey round suggest that mobile phone ownership is associated with fertility through role modeling, preference change, and access to information.

\footnotetext{
${ }^{1}$ Department of Social and Political Sciences, Bocconi University, Milan, Italy; Dondena Centre for Research on Social Dynamics and Public Policy, Bocconi University, Milan, Italy. Email: francesco.billari@unibocconi.it.

2 Department of Sociology, University of Oxford and Nuffield College, Oxford, UK; Dondena Centre for Research on Social Dynamics and Public Policy, Bocconi University, Milan, Italy. Email: valentina.rotondi@sociology.ox.ac.uk.

${ }^{3}$ Department of Sociology, University of Chicago, Chicago, USA. Email: jennytrini@uchicago.edu.
} 


\section{CONCLUSIONS}

Mobile phone ownership is associated with fertility via role modeling, preference change, and access to information rather than through substitution effects.

\section{CONTRIBUTION}

Bridging the digital divide may hasten the fertility transition in sub-Saharan Africa.

\section{Introduction}

Digital technologies have revolutionized people's lives and everyday activities worldwide. One component of this digital revolution is the "mobile phone revolution" - the advent and diffusion of cheap, ubiquitous, and multitasking mobile phones. This mobile phone revolution has been profound and widespread and is playing out in unique ways in developing settings, many of which have leapfrogged over the landline stage of development and moved straight into the wireless age. According to a 2016 Afrobarometer report, a far greater proportion of Africans have access to cell phone service than to a proper drainage system, electricity, paved roads, or piped water (Mitullah et al. 2016).

With an eye to the particular features that characterize the digital revolution in developing contexts, social scientists have started to examine the institutional, geographic, and socioeconomic inequalities that underpin the digital revolution and measure their consequences. The term "digital divide" (Norris 2001; DiMaggio et al. 2001) describes the multidimensional digital inequalities related to: physical opportunities to access digital technology in a specific area (i.e., the presence and quality of the necessary infrastructure) (Buys et al. 2009); socioeconomically structured opportunities to access digital technology (i.e., to own a mobile phone or be able to access the internet) (Roycroft and Anantho 2003); and socioeconomically structured capabilities to effectively use digital technologies (i.e., to retrieve useful information through the internet) (Hargittai 2002).

A growing body of empirical literature from low-income settings shows that mobile phone ownership positively affects market performance (Jensen 2007; Aker 2010; Aker and Fafchamps 2014), household income (Blauw and Franses 2016; Hübler and Hartje 2016), education (Aker, Ksoll, and Lybbert 2012), and under certain circumstances political participation (Manacorda and Tesei 2020). Health-care interventions based on mobile phones can improve the delivery of health services, including access to antiretroviral (Lester et al. 2010) and malaria therapies (Zurovac et al. 2011). Furthermore, "mobile money" transfer services help smooth consumption in the face of economic shocks (Jack and Suri 2014; Munyegera and Matsumoto 2016), thereby reducing food insecurity (Murendo and Wollni 2016) and increasing financial resilience and savings (Suri and Jack 2016). 
In this paper, we link the digital revolution to what might seem, at first sight, a more distal outcome: fertility. Specifically, we focus on the relationship between mobile phone ownership and childbearing in a high-fertility setting of sub-Saharan Africa. A sizable literature spanning three decades and multiple continents has clearly established that campaigns based on unidirectional mass media have helped speed up the fertility transition in developing contexts (for a review, see Della Vigna and La Ferrara 2015). But the unique role of digital technologies, especially the mobile phone revolution, on fertility has not yet been investigated empirically.

Our analyses exploit the richness of the Tsogolo la Thanzi (TLT) longitudinal study conducted in Balaka, Malawi, between 2009 and 2015. As a preview, using fixed-effects panel data models we show that mobile phone acquisition, ownership, and use are associated with smaller ideal family size and lower parity during the study period. Complementary cross-sectional analyses from a later survey round suggest the main pathways by which mobile phone ownership is linked to fertility: role modeling, preference change, and access to information. Furthermore, Cox proportional hazard models clarify that mobile phones are not fundamentally linked with changes in women's earliest steps in family formation but with fertility trajectories on a longer time-horizon through child spacing.

\section{Background and context}

\subsection{Conceptual background}

In a decisive analysis of fertility transitions, Bongaarts (Bongaarts 2017) characterizes Africa's fertility transition as unique in four key ways: It is later (in terms of timing), earlier (in terms of level of development at the onset of the transition), slower (in terms of the pace of fertility decline), and higher (in terms of the fertility levels at a given level of development). The slow pace of the African fertility transition has been of particular concern to population scholars.

We posit here that the spread of digital technologies, mobile phones in particular, may be contributing to the recent acceleration of Africa's unique fertility transition, hypothesizing that mobile phones can influence fertility through four possible pathways. First, mobile phones can reduce information search costs (Aker 2010), thus helping individuals make informed decisions about many issues, including contraception. Mobile phone technologies may also amplify the traditional social learning paths long recognized as drivers of fertility change (Montgomery and Casterline 1996; Bongaarts and Watkins 1996). While social learning was previously restricted to personal social networks and mass media, digital technologies have opened up new paths and altered the salience of particular paths relative to others. For instance, in a study set in the Nyanza province, Kenya, Kohler and colleagues showed that social learning through in-person social net- 
works was an especially important mechanism in fertility choices in areas with lower exposure to markets (Kohler, Behrman, and Watkins 2001). In general, social learning is thought to be particularly relevant in poor areas, where information is scarce and preferences tend to be loosely held (La Ferrara 2016). We refer to this pathway as information provision.

Second, social networking sites (e.g., Facebook, Instagram, and the like) provide users with access to "the lives of others," which might affect the desirability and social acceptability of certain behaviors, such as having many children or using contraceptives. Such influences have been observed for unidirectional mass media such as television (La Ferrara, Chong, and Duryea 2012). Digital technologies can amplify these wellestablished social-influence paths to fertility change, which were previously thought of as restricted to personal social networks and mass media (Montgomery and Casterline 1996; Bongaarts and Watkins 1996). We refer to this pathway as role modeling.

Third, mobile phones can increase economic well-being and financial inclusion (Aker and Mbiti 2010), which in turn can influence fertility preferences. A key instrument is the development and diffusion of mobile money services (Suri and Jack 2016). In the absence of efficient credit markets, stable currency, and stable governance, children constitute a buffer against economic shocks (Dillon 2013) and are crucial sources of income - both directly (through involvement in formal wage employment) and indirectly (through involvement in domestic activities, particularly hazardous chores). By improving financial inclusion, mobile phones could reduce the demand for children by essentially self-insuring households, especially the most vulnerable, against unexpected shocks. We refer to this demand-based pathway as preference change.

Fourth, like other modern forms of communication (Rosenfeld and Thomas 2012; DiMaggio et al. 2001), mobile phone use may index a relative lack of embeddedness in more traditional social institutions. While not antithetical to developing romantic relationships per se, the ability to maintain personal ties from a distance may grant phoneowning women greater levels of independence from face-to-face interactions, including the kinds of romantic and sexual relationships that are most likely to facilitate pregnancy and a subsequent birth (Miller-Ott, Kelly, and Duran 2012; McDaniel and Coyne 2016; Rotondi, Stanca, and Tomasuolo 2017). If, for example, mobile phones tend to facilitate long-distance relationships, ownership may be associated with lower levels of coital frequency. If phones facilitate casual sexual encounters, we would expect lower levels of coital frequency paired with higher levels of barrier contraceptive use. We refer to this pathway as substitution effect.

All four pathways depend on access to mobile phones. But access, of course, is never equal; access to digital technologies is socially stratified (DiMaggio et al. 2001; 
Norris 2001). The key aspect of the digital divide we study is mobile phone ownership, which indexes access to and use of digital technologies given the existing infrastructure. ${ }^{5}$

\subsection{Study context}

To explore the relationship between technology and fertility, we rely on data from the Tsogolo la Thanzi (TLT) panel study set in Balaka, southern Malawi, between 2009 and 2015. Digital technologies came late to Malawi, and the country remains among the most expensive in the world for mobile phone use (ITU 2014).

Our population of interest is young women who are in the early stages of their reproductive careers. Three macro-level features of the study context are worth noting in more detail: (1) the socioeconomic backdrop; (2) the fertility patterns characterizing the region, the country, and this period of the life course; and (3) the proliferation of mobile phones - not just in Malawi but across sub-Saharan Africa - over the course of the study period.

First, with respect to the socioeconomic situation, Malawi is one of the world's poorest countries. Within the country, southern Malawi features especially low levels of educational attainment and higher levels of poverty when compared to the central and northern regions. In other words, the small corner of the world in which our study is set is marked by disadvantages even within its own national context (NSO and ICF 2011, 2017).

Second, although fertility in Malawi has been declining in recent decades (falling from almost seven children per woman in the early 1990s), it remains high (TFR stood at 4.4 children per woman in 2015), and childbearing still begins early - at around age 19 nationally, slightly earlier in the southern region (NSO and ICF 2017). The age-specific fertility rate (ASFR) for 15- to 19-year-old Malawian women in 2010 was about 150 births per thousand; the ASFR peaks for women age 20 to 24 (at slightly over 250) and then declines. The TLT study, based in a high-fertility setting, observed young women during the period of the life course that is most salient for understanding fertility trajectories.

Third, Malawi generally and Balaka in particular are subject to the same technological forces that swept the entire subcontinent in the past decade. According to the International Telecommunication Union's 2009 report on Africa, mobile cellular penetration rose dramatically across the region, from less than $2 \%$ in 2000 to an estimated $33 \%$ in 2008 (ITU 2010), and it consistently grew after 2010 (ITU 2014). Not surprisingly given

\footnotetext{
${ }^{5}$ Since at least 2008, cell phone service coverage in our study setting has been thorough and is offered by two different service providers; the infrastructure itself exists across the catchment area, so we are not concerned with the possibility that non-ownership would be conflated with a lack of infrastructure/service. Our analyses will shed some light on the possibility that opportunities to access digital technologies have a socially-stratified effect within specific settings, that is, a "second-level digital divide" (Hargittai 2002).
} 
the country's economic profile, cell phone penetration in Malawi lags behind the region as a whole; in 2008, cell phone usage stood at about $8 \%$, internet use was estimated at 2.2 per 100 inhabitants, and an estimated $4 \%$ of households had a computer. In section 3.5 we use TLT data to give descriptive evidence of mobile phone diffusion in southern Malawi.

\section{Data, measures, and methods}

To provide a deep and detailed understanding of the changes that characterize young adulthood in a low-resource, high-fertility setting, the TLT study collected eight waves of data at closely-spaced intervals (every four months) for a period of three years. The initial sample, drawn in 2009, comprised 1,500 female and 600 male respondents between the ages of 15 and 25 residing in census enumeration areas within seven kilometers of the district capital. The response rate at baseline was $95.6 \%$; at every subsequent wave, TLT collected detailed information at the individual and household levels, providing detailed and dynamic information on personal and household goods, household composition, and fertility-related behaviors and outcomes. Respondents were interviewed up to eight times between the baseline survey and December 2011. Three years later, between June and September 2015, TLT fielded a follow-up survey that included a module about media and information and communication technology (ICT). By this time, the youngest members of the cohort had turned 21 and the oldest $31 ; 80 \%$ of the original sample of women were reinterviewed in $2015 .^{6}$

\subsection{Key fertility measures}

We study fertility preferences and outcomes, anchoring our analyses to outcomes. We first aim to understand whether and to what extent parity - operationalized as children ever born, obtained from complete birth histories - is associated with mobile phone ownership. We also test for differences in fertility preferences, operationalized as ideal family size (IFS), which is frequently used to proxy demand for children in developing settings and ranges from 0 to 12 in our sample (mean $=3.31$ ). The precise prompt for our IFS measure asked: "People often do not have exactly the same number of children they want to have. If you could have exactly the number of children you want, how many children would you want to have?"

\footnotetext{
${ }^{6}$ See the Appendix for a detailed discussion of attrition in the TLT study.
} 


\subsection{Key measures of mobile phone ownership}

Mobile phone ownership is measured at every wave as a response to the question: "Do you, yourself, own a mobile phone?" (with answers coded 0 for no and 1 for yes). In other words, we focus on the respondent herself rather than on the presence of any phone in the household. Overall, cell phone prevalence expands over time, but individual respondents can (and do) gain and lose phone ownership from wave to wave.

In the follow-up round of data collection fielded in 2015, TLT included an expanded module about technology use that allows us to explore the processes by which phone use may be associated with certain outcomes. Among phone owners, we disaggregated phone use along several dimensions: phone calls, sending/receiving SMS messages, sending/receiving mobile money, internet, and watching videos or listening to music.

\subsection{Micro-level analogs to the proximate determinants of fertility}

To gain clarity on the processes by which parity, in particular, should be linked to mobile phone ownership, we examine a set of intervening variables, both as intermediate outcomes and as predictors. This array of variables can be thought of as micro-level analogs to the proximate determinants of fertility that are frequently used in the literature (Bongaarts et al. 1978), including marital status $(1=$ currently married, $0=$ any other marital status), coital frequency using women's self-reports (measured in the past month, top-coded at the 99th percentile and ranging from 0 to 30), and current use of a modern contraceptive method (coded 1 if the respondent reports using condoms every time or almost every time, birth control pills, injectables, Norplant, an IUD, or sterilization; coded 0 otherwise). All three measures vary by wave.

\subsection{Time-varying control variables}

As controls, we include time-varying measures of:

- Age: measured in months so that it can vary from one wave to another.

- Educational attainment: measured in completed years and divided into three groups (no education, some primary, some secondary) for certain portions of our analyses. See Figure A-1 for a graphical depiction of the distribution of education at baseline. In cases where respondents advanced (for example) from Standard 2 to Standard 3 in a period of four waves, the data we collected is read as $2-2-2-3$. However we restructured the data for our analyses as $2-2.33-2.67-3$. In cases wherein respondents had completed their schooling or were schooling but did not advance 
to the next level, we did not add fractions of a year and left the analytic values as 5 - 5 - 5 - 5 - 5 .

- Income in the past month: the logarithm of the monthly earnings originally reported in Malawian kwacha.

- Household wealth: measured by a linear index comprised of household structural assets (e.g., flooring and roofing material, water supply, sanitation) with weights calculated for each asset using principal-components analysis. The wealth variable is divided into quartiles for certain portions of our analyses. As a further robustness check, Table A-4 in the Appendix contains estimates from the model described in equation (1), which adjusts for household wealth measured in different ways.

- Ownership of two other, expensive household goods: Television (to control for potential confounding effects driven by other technologies used to access information [La Ferrara 2016]) and a refrigerator (a measure of the capability of the household to protect itself from food poverty through safe storage of perishable food item [Zereyesus et al. 2017]).

Table 1 provides additional details about item construction and summary statistics for all measures.

\subsection{Analytic approach}

Our analyses proceed in five parts.

\section{Descriptive}

First, we describe the digital divide in mobile phone ownership in Balaka.

\section{Bivariate}

Second, we present the gross differences in children ever born between phone-owning and non-phone-owning women to establish the magnitude of this divide with respect to fertility.

\section{Fixed-effects panel models}

The third part is the centerpiece of our analyses: We leverage data from all women over eight waves to estimate the relationship between mobile phone ownership and fertility preferences and outcomes using fixed-effects panel models. ${ }^{7}$ Here we follow Behrman and colleagues' (2002) analysis of contraceptive choice in a high-fertility setting and

\footnotetext{
${ }^{7}$ TLT collected detailed information on births, but the exact date of cell phone acquisition is unknown; for this reason, event-history models cannot be reliably used to answer our questions.
} 
Bachan's (2014) approach to estimating change using TLT data. Our specific identification strategy leverages a panel data fixed-effects model as depicted in equation (1):

$$
y_{i t}=\beta_{1}\left(x_{1 i t-3}\right)+\beta_{2} x_{2 i}+\alpha_{i}+\eta_{i t},
$$

where $y_{i}$ is parity for individual $i$ and $x_{1 i}$ is a dummy variable set to a value of 1 if the respondent owns a mobile phone, 0 otherwise. Data on mobile phone ownership was collected at every wave of the TLT survey; in our analyses the measure is lagged by three waves $\left(x_{1 i t-3}\right)$ (i.e., about 12 months) to capture the timing of pregnancies rather than the timing of births. $x_{2 i}$ is our set of control variables. $\eta_{i t}$ is the idiosyncratic error component, i.i.d. $\left(0, \sigma_{\eta}^{2}\right)$, uncorrelated with $\left(x_{1 i t}, x_{2 i}, \alpha_{i}\right)$, and $\alpha_{i}$ is i.i.d. $\left(0, \sigma_{\alpha}^{2}\right)$, potentially correlated with $x_{1 i t}$ and $x_{2 i}$. Assuming that omitted variables are time-invariant (with time-invariant effects), a fixed-effects panel estimator adjusts for omitted variable bias and is the most conservative test we can use. ${ }^{8}$

The empirical analyses presented in this paper rely on an unbalanced panel dataset. Because attrition is not strongly patterned along our dimensions of interest, we are not overly concerned about sample selection biasing our estimates. Moreover, replicating the models on the balanced panel produced substantively identical results.

Given space constraints and the overall consistency of the results from these various specifications (fixed versus random effects; balanced versus unbalanced panel), we focus our discussion on estimates generated by fixed-effects models generated by the unbalanced panel. All respondents who contributed at least two waves to the study are included ( $\mathrm{N}=10,557$ person-waves from 1,498 women). All key relationships were confirmed by models that featured other combinations of specifications.

While we kept equation (1) as our main model also for its relative simplicity, we fitted an additional series of models taking into consideration that our dependent variable is a count (Allison 2009). We estimated random, pooled, and fixed-effects Poisson models, but given the data on children ever born, our preferred generalized Poisson model is a hybrid zero-inflated Poisson regression model. This model is appropriate since our data present overdispersion because of zero-inflation, specifically a concentration of observations at parity zero (Melkersson and Rooth 2000). The hybrid zero-inflated Poisson approach allows us to avoid misspecification and inflated Type I errors (Perumean-Chaney et al. 2013) by estimating a model that consists of two parts: a Poisson count model including all time-varying covariates expressed as deviations from individual-specific

\footnotetext{
${ }^{8}$ We also estimated a series of random-effects models with more efficient estimators. This specification allows us to retain cases in which mobile phone ownership is consistent throughout the study (i.e., always own, never own) and estimate the parameters of time-invariant regressors. But the random-effects models behave inconsistently with respect to unobservable effects that could be correlated with key covariates. To compare the estimates from fixed- and random-effects models, we performed Hausman tests of the null hypothesis that the individual-specific components of the error term $\left(\alpha_{i}\right)$ are uncorrelated with the regressors.
} 
means (Allison 2005) ${ }^{9}$, and a Logit model for predicting excess zeros. Excess zeros are assumed to be generated by a separate process from other count values. In our case, we model whether a women has any child simply as a function of her age at baseline. The results of those additional analyses are depicted in Table A-2 in the Appendix and are consistent with our main findings ${ }^{10}$.

Table A-4 in the Appendix contains a series of robustness checks to corroborate our findings.

\subsubsection{Cox proportional hazard models}

Fourth, we present estimates from a trio of Cox (1972) proportional hazard models. The basic specification for the hazard model is standard, as follows:

$$
h(t)=h_{0}(t) \exp \left(\beta_{1} x_{1}+\beta_{2} x_{2}\right),
$$

where $h(t)$, the hazard function at time $t$, is determined by the baseline hazard $h_{0}(t) . x_{1}$ represents cell phone ownership, with $\beta_{1}$ as its effect on the hazard, and $x_{2}$ represents a vector of time-varying covariates including education, wealth, television ownership, and marital status (in cases in which the outcome is birth), with $\beta_{2}$ as the vector of parameters. We measure time in survey waves and use self-reports of marital status and parity to construct the three outcome measures, analyzing:

1. Time to first marriage among women who were not married at the start of the study

2. Time to first birth among women who were childless when the study began in 2009

3. Time to second (or subsequent) birth for women who had at least one child during the course of the study

Because our sample is relatively young (ages 15-25 in 2009; ages 21-31 in 2015), and respondents have not completed their reproductive careers, this approach helps clarify the extent to which phone ownership may be associated with childbearing through union formation (i.e., later marriage), the initiation of childbearing (i.e., delayed first birth), or birth spacing (i.e., longer birth intervals or postponement).

\footnotetext{
${ }^{9}$ Covariates are expressed as deviations from individual-specific means, because in nonlinear models the fixed effects are conditioned out of the likelihood, which is then maximized (Allison and Waterman 2002). Notice that a model including individual-level dummies - the so-called unconditional model, which is much more computationally intense - leads to unchanged results.

${ }^{10}$ As suggested above, the lack of significance for the mobile phone ownership coefficient in the fixed-effects Poisson model can be explained by the zero-inflated nature of our count data.
} 


\subsubsection{TLT-2 (2015) cross-section}

Finally, we present cross-sectional, multivariable analyses of a follow-up survey conducted in 2015. Here we consider the relationships between phone ownership, phone borrowing, and type of phone use, and ideal family size, contraceptive use, and parity. We predict IFS using a linear model, contraceptive use using a probit model, and parity using a Poisson model. ${ }^{11}$

\section{Results}

\subsection{Balaka's digital divide: Mobile phone ownership, 2009-2015}

Before examining the relationship between mobile phone ownership and fertility, we first establish the magnitude of the mobile phone revolution in this part of the world by describing the expansion of mobile phone use among young women in Balaka between 2009 and 2015, and the extent to which this expansion is socially stratified, thus creating a digital divide.

\footnotetext{
${ }^{11}$ Since women are older and most of them have had at least one child by 2015 , we do not detect a dispersion problem at 0 .
} 
Billari, Rotondi \& Trinitapoli: Mobile phones, digital inequality, and fertility

Figure 1: $\quad$ Trends in mobile phone ownership in Balaka (2009-2015)
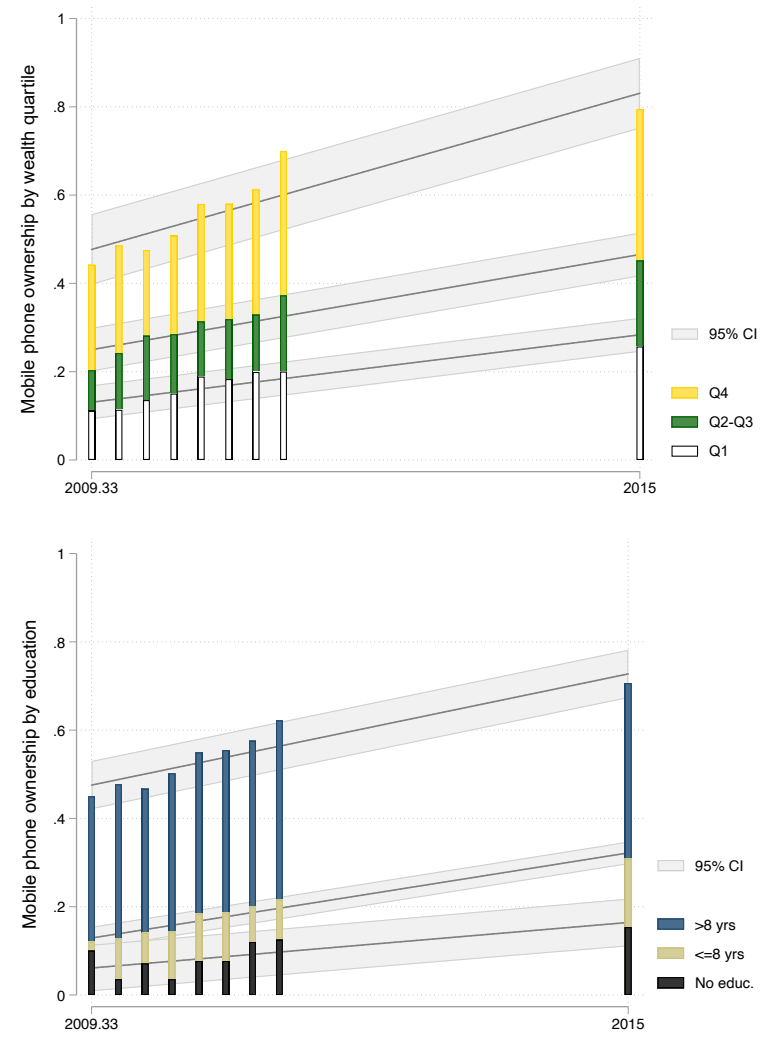

Source: Authors' graphical elaboration from TLT-1 and TLT-2 data. Years: 2009-2015. 
Table 1: $\quad$ Summary statistics

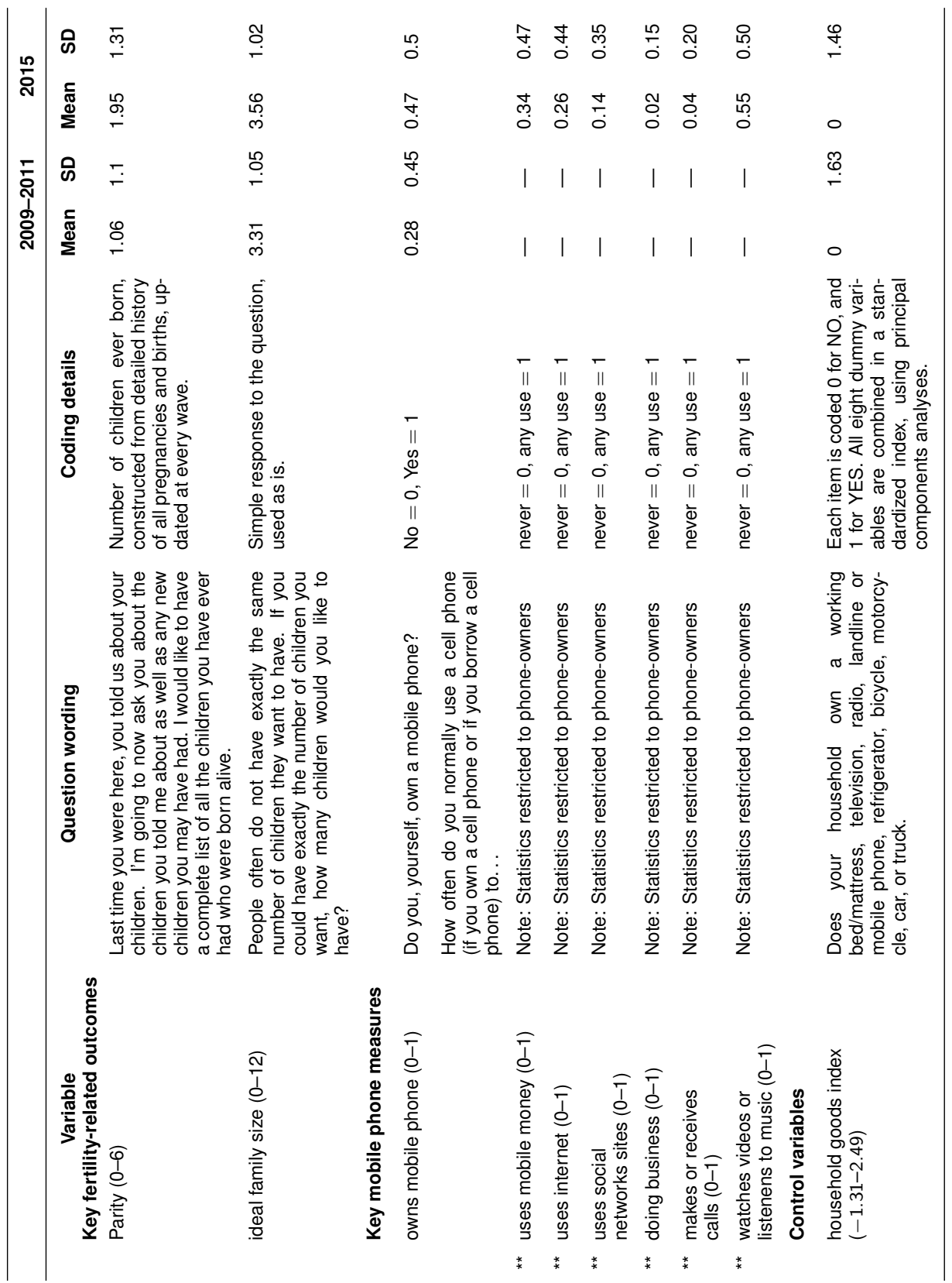


Billari, Rotondi \& Trinitapoli: Mobile phones, digital inequality, and fertility

Table 1:

(Continued)

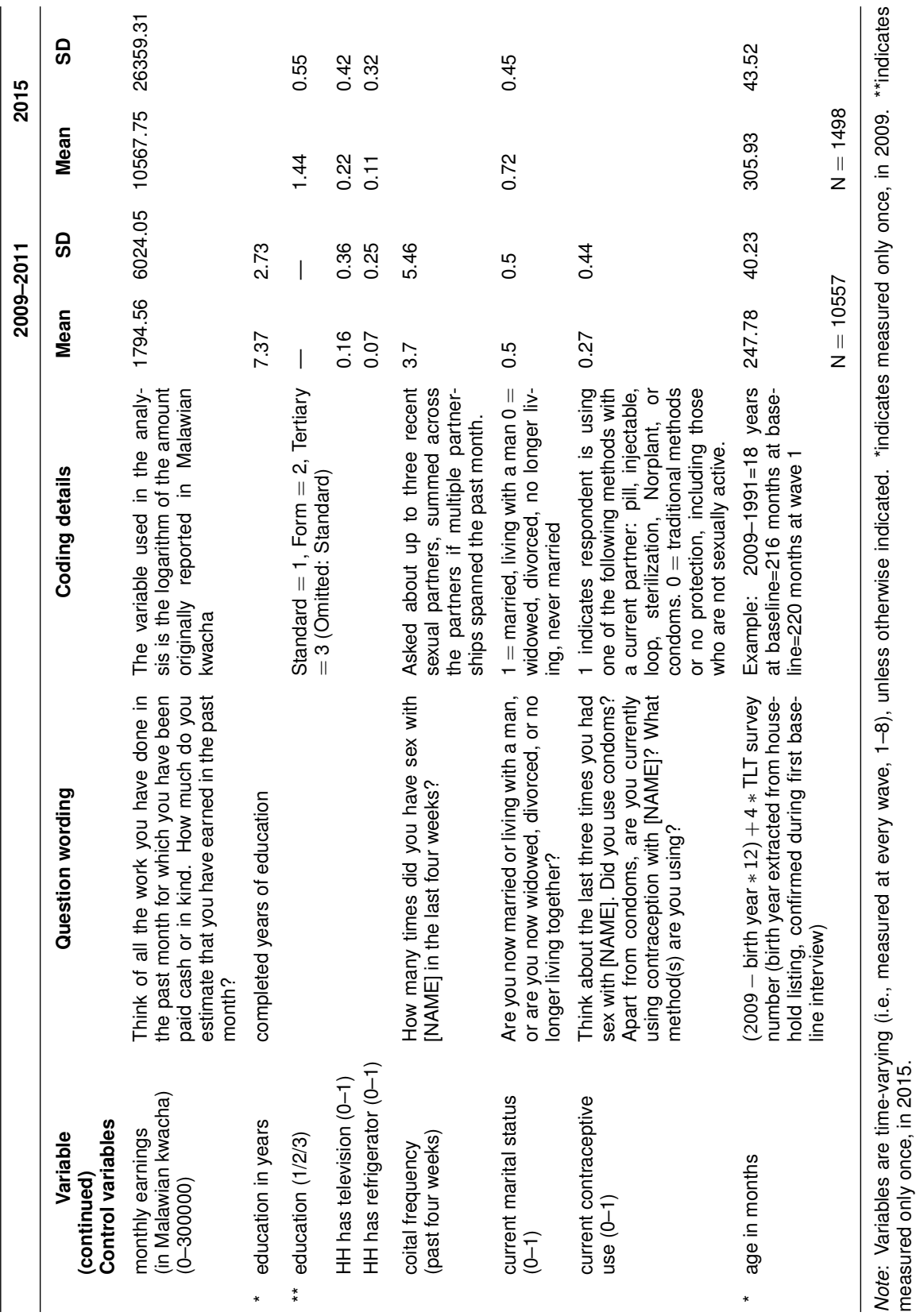


As Table 1 shows, phone ownership was relatively rare when TLT began in late 2009 (22\%), but as described by the ITU report (ITU 2014), phones proliferated throughout Malawi over the course of the study period. By the end of TLT's intensive longitudinal portion (late 2011), 35\% of the women said they owned a mobile phone, and by the time of the follow-up survey in 2015, nearly half of the women in the study (47\%) owned a mobile phone. This is a dramatic transformation for a relatively short time span. As shown in Figure 1, mobile phone ownership was, and continues to be, stratified by education level (upper panel) and by household wealth (lower panel). The pace of diffusion, however, as measured by the slope, is comparable for each group. In other words, the digital divide is evident in the education-wealth gradients, but the divide itself in Balaka neither grew nor shrank during this period.

Results from TLT are consistent with the latest available DHS data on Malawi (NSO and ICF 2017), which show that in 2014, $25 \%$ of women with primary education said they owned a mobile phone, compared with $57 \%$ of women with secondary education and $97 \%$ of women with more than secondary education.

\subsection{Mobile phone ownership and fertility: A bivariate view}

Figure 2 show the patterning of fertility (children ever born) and fertility preferences (IFS) over time by mobile phone ownership. Overall, the rise in average number of children per woman is significantly steeper (red columns in Figure 2) among women without mobile phones than among women who own phones (black columns in Figure 2). Although there is no clear difference at the very beginning of the study in 2009, differences emerge in 2010 and grow to staggering proportions. By the time of the 2015 follow-up survey, the differential is nearly one full child $(1.55$ vs. $2.40, \mathrm{p}<.001)$. However, this difference might not be (entirely) driven by changes that can be attributed to the spread of mobile phone ownership, as other factors are important. Some of these factors are important (e.g., education, socioeconomic status, age) and some of them are unobservable (e.g., genetic differences, motivation, forward-looking behavior). In what follows, we leverage a variety of estimation tools to further unpack and explain this differential. It is instructive that the observed differences in IFS follow the expected pattern - non-owners desire more children than owners and the difference grows over time. However, the observed gap in fertility preferences is substantially smaller than the one for children ever born; the largest difference between owners (mean IFS $=3.30$ ) and non-owners (mean IFS = 3.79) never exceeds .40. 
Figure 2: Children ever born and ideal family size by mobile phone ownership over time (2009-2015)

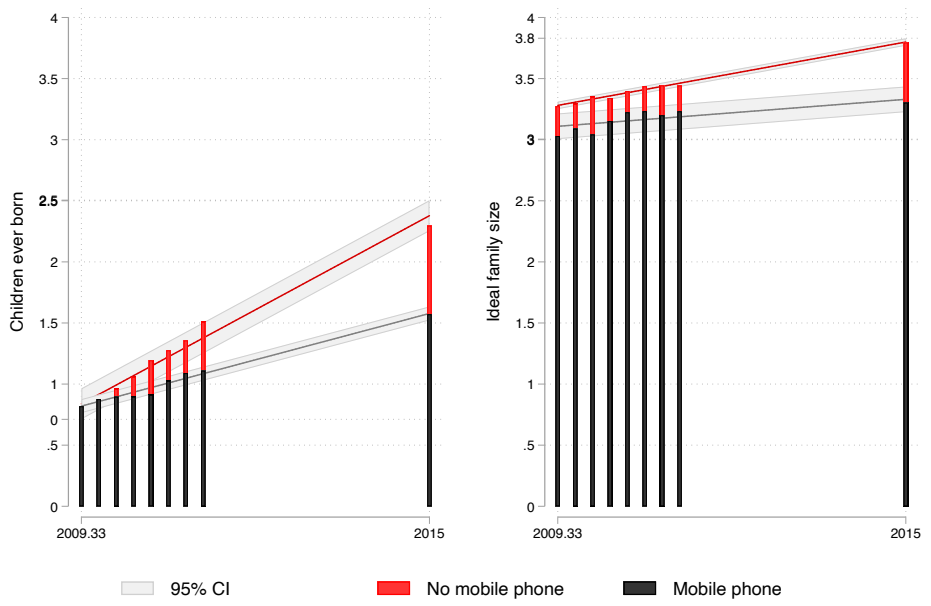

Source: Authors' graphical elaboration from TLT-1 and TLT-2 data. Years: 2009-2015.

\subsection{Mobile phone ownership and fertility: Panel data estimates}

Tables 2 and 3 contain the results of our main empirical analyses. In column 1 of Tables 2 and 3, we show estimates from equation (1), using ideal family size (IFS) and parity (children ever born), respectively, as dependent variables. These models estimate change in the dependent variable, controlling for the time-varying individual-level characteristics listed in Table 1. 
Table 2: $\quad$ Relationship between mobile phone acquisition and IFS

\begin{tabular}{|c|c|c|c|}
\hline & (1) & (2) & (3) \\
\hline owns mobile phone & $\begin{array}{c}-0.0319+ \\
(0.0188)\end{array}$ & & \\
\hline owns mobile phone $(t-2)$ & & $\begin{array}{l}-0.0038 \\
(0.0228)\end{array}$ & \\
\hline owns mobile phone $(t-3)$ & & & $\begin{array}{c}0.0019 \\
(0.0258)\end{array}$ \\
\hline monthly earnings (in Malawian kwacha, log) & $\begin{array}{l}-0.0021 \\
(0.0020)\end{array}$ & $\begin{array}{l}-0.0020 \\
(0.0020)\end{array}$ & $\begin{array}{l}-0.0008 \\
(0.0022)\end{array}$ \\
\hline age (in months) & $\begin{array}{c}0.0054^{* * *} \\
(0.0009)\end{array}$ & $\begin{array}{c}0.0052^{* * *} \\
(0.0011)\end{array}$ & $\begin{array}{c}0.0042^{* *} \\
(0.0013)\end{array}$ \\
\hline $\mathrm{HH}$ has television & $\begin{array}{l}-0.0659 \\
(0.0340)\end{array}$ & $\begin{array}{l}-0.0252 \\
(0.0384)\end{array}$ & $\begin{array}{l}-0.0113 \\
(0.0387)\end{array}$ \\
\hline $\mathrm{HH}$ has refrigerator & $\begin{array}{l}-0.0152 \\
(0.0519)\end{array}$ & $\begin{array}{l}-0.0179 \\
(0.0565)\end{array}$ & $\begin{array}{l}-0.0646 \\
(0.0516)\end{array}$ \\
\hline
\end{tabular}

Note: All variables described in Table 1. Coefficients derived from fixed-effects OLS models. Cluster-robust standard errors in parentheses. $+p<0.10,{ }^{*} p<0.05,{ }^{* *} p<0.01,{ }^{* * *} p<0.001$.

Source: TLT-1 waves $1-8$.

The estimated coefficient for mobile phone ownership on IFS is small and negative marginally significant at the $10 \%$ level - in model 1 of Table 2. models 2 and 3 (Table 2) specify different lags to test whether phone acquisition may have delayed consequences for fertility preferences. These models reveal no significant change in IFS either four months or eight months after a phone was acquired. So, to the extent that phone acquisition dampens fertility preferences, the association is small and contemporaneous. In line with expectations, fertility preferences tend to rise with age, or over time, in this young sample. And in contrast to some other studies of technology and ideational change (Faria and Potter 1999; La Ferrara, Chong, and Duryea 2012; Thornton 2001), women living in households that acquire a television set do not change their preferences in any meaningful way. Recalling Figure 1, to the extent that mobile phone owners have fewer children than do non-owners, this difference cannot be attributed to either the enactment of a smaller IFS or to preference change.

Table 3 shifts our focus to parity. While in Table 2, all covariates were measured contemporaneously with the dependent variable, in Table 3, use of a mobile phone, IFS, coital frequency, marital status, and contraception are lagged by three waves (12 months to predate an associated pregnancy and subsequent birth nine months later).

As shown in model 1 , starting to own a mobile phone is associated with a slower increase in parity over time. The fixed-effects model treats mobile phone ownership symmetrically, meaning that the loss of a mobile phone is associated with more rapid increases in parity over time; the relationship is robust to shifting fertility preferences 
(model 2). Models 3 through 5 of Table 3 display estimates that adjust for proximate determinants of fertility, and model 6 adjusts for all controls and covariates jointly. By including potential pathways in the model, we aim to gauge the extent to which the estimated effect of mobile phone ownership on fertility might be explained by differences in related attitudes, statuses, and behaviors. The estimated effects of the control variables for all six different specifications in Table 3 are in line with expectations generated by decades of literature on fertility across contexts: Age/time, transitions to "currently married" as one's marital status, and increases in coital frequency are all positively related to parity. And women who report using any modern form of contraception three waves prior to the measured outcome have fewer children. The negative association with phone ownership (i.e., acquisition in a fixed-effects framework) is consistent in size and significance across all six models.

\subsection{Phones and family formation}

The fact that fertility, measured as children ever born, differs by mobile phone ownership among young adult women in Balaka is readily apparent from Figure 2 and elaborated further in the previous section. The process by which this difference is manifest, however, is still unclear. The fixed-effects estimation approach ensures that the observed association is not driven by omitted variables, but the pathway through which the two groups diverge cannot be identified. Because cell phones themselves cannot cause fertility to decline (not in the true sense of the word), we must think carefully and creatively about the behavioral pathways that organize and explain this observed association. To shed additional light on the divergence in the fertility trajectory of phone-owning versus non-phone-owning women, we estimated a series of Cox proportional hazard models, described in equation (2), to examine trends in (1) first marriage, (2) first birth, and (3) second birth.

The underlying models (shown in Table A-4) adjust for the same core set of covariates that were included in the fixed-effects models and allow us to estimate the relationship of mobile phone ownership with the hazard of each event for the population at risk: never-married women, women at parity 0 , and women at parity $1 .{ }^{12}$ Results from these models are plotted in Figure 3 (and in Table A-3 in the appendix) and suggest no meaningful difference between the two groups in time to first marriage or first birth. Nevertheless, the third panel shows evidence of divergence between the two groups for the transition to parity 2. Net of age, education, and a host of other relevant covariates, women who own cell phones are significantly less likely to experience a second birth during the study period (coefficient $=-0.147$; hazard ratio $=0.863$ ), which we interpret as evidence of longer first birth intervals (i.e., postponement) for this group. In other

\footnotetext{
12 Because very few women had three or more children during the study period, estimates for higher-order births are unstable. We do not present these results here, but they are available upon request.
} 
words, the first steps of family formation are similar for mobile phone-owning women in Balaka and for non-owners, but their fertility trajectories begin to diverge at "the second space" (Johnson-Hanks 2004). This finding is consistent with a large literature on the importance of child spacing and postponement for understanding fertility patterns in subSaharan Africa (Johnson-Hanks 2004; Paz Soldan 2004; Timæus and Moultrie 2008).

\section{Figure 3: $\quad$ Hazard rates by phone ownership}
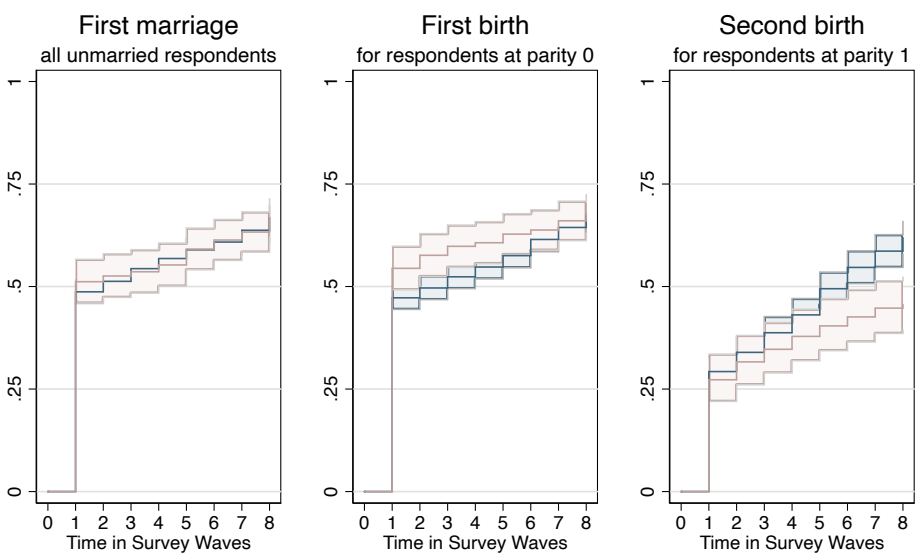

No Phone 95\%

Phone 95\%

No Phone

Owns Phone 
Table 3: $\quad$ Relationship between mobile phone acquisition and children ever born

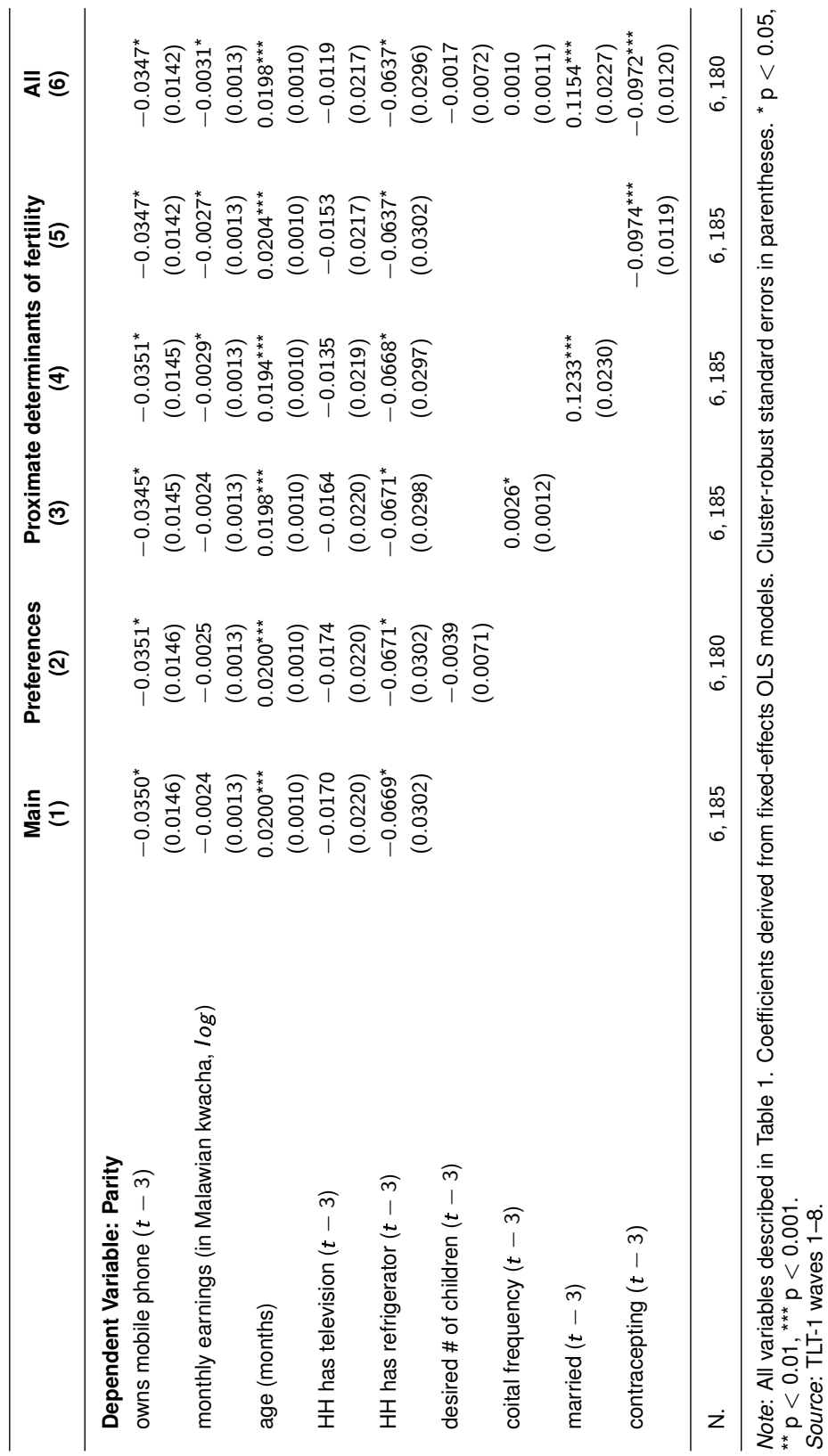




\subsection{From phone ownership to phone use}

So far, we have focused exclusively on mobile phone ownership and its relationship to fertility outcomes and preferences. Fixed-effects models show that the effect of acquiring a mobile phone is robust to omitted variable bias, and Cox proportional hazard models show that the differences between owners and non-owners are most salient after a first birth. We interpret these results as evidence of a change in preferences toward smaller families and the manifestation of this preference in child spacing.

A key feature of mobile phones is that they subsume a variety of technological tools. Even the most basic phones allow users to make phone calls, send and receive text messages, take photos, transfer money, listen to music, watch videos, and search the internet - all while on the move. Here we exploit cross-sectional data from the 2015 follow-up round of TLT, in which women who enrolled in the study in 2009 were reinterviewed and asked a set of more detailed questions about mobile phone use. These analyses move beyond phone ownership to begin exploring how patterns of mobile phone use are associated with fertility preferences and parity.

As depicted in Table 1, in 2015, more than $40 \%$ of women in the sample were using their mobile phones to send messages and make calls, but only $14 \%$ were accessing the internet $^{13}$, and just one in five were making mobile money transactions using mobile phones. ${ }^{14}$ To identify which, if any, aspects of phone use are correlated with fertility preferences and actual fertility, we estimate a set of simple regression models, adjusting for the same set of controls used throughout this paper. The results, presented in Table 4 , indicate that from a cross-sectional view, not all forms of phone use have the same relationship to fertility-related outcomes.

\footnotetext{
13 Although we cannot perfectly disentangle the differences between owning a mobile phone, a feature phone, or a smartphone, we can say with certainty that having internet access via the phone is a good proxy for phones with advanced capabilities, that is, not just mobile phones.

${ }^{14}$ Among women who are phone-less, $72 \%$ still have access to a mobile phone because they borrow one. Phoneless women declare that they do not own a phone because it is expensive $(75 \%)$, because they do not need it $(11 \%)$, because it is broken (10\%), or because the husband/partner or parents do not allow them to have it (2\%). The remaining $2 \%$ said they owned a phone previously but the phone was lost/stolen or sold. The average age at first cell phone ownership in our sample is 20 .
} 
Table 4: $\quad$ Associations between mobile phone ownership and fertility-related outcomes: 2015 cross section

\begin{tabular}{|c|c|c|c|c|}
\hline & \multirow[t]{2}{*}{ (1) } & \multirow[t]{2}{*}{ (2) } & \multirow{2}{*}{\multicolumn{2}{|c|}{ Contraception }} \\
\hline & & & & \\
\hline & Children ever born & Ideal family size & All mod. methods & Ever used condoms \\
\hline \multirow{2}{*}{$\begin{array}{l}\text { owns mobile } \\
\text { phone }\end{array}$} & $-0.141^{* \star *}$ & $-0.051^{\star *}$ & -0.006 & 0.054 \\
\hline & $(0.031)$ & $(0.016)$ & $(0.023)$ & $(0.030)$ \\
\hline \multirow[t]{2}{*}{ age } & $0.082^{* * *}$ & $0.017^{\star \star *}$ & -0.003 & $-0.010 *$ \\
\hline & $(0.005)$ & $(0.002)$ & $(0.003)$ & $(0.004)$ \\
\hline married/cohabiting & $\begin{array}{c}0.413^{\star * \star} \\
(0.047)\end{array}$ & $\begin{array}{l}0.095^{\star \star \star} \\
(0.019)\end{array}$ & $\begin{array}{l}-0.047 \\
(0.027)\end{array}$ & $\begin{array}{c}-0.285^{\star \star \star} \\
(0.026)\end{array}$ \\
\hline \multirow{2}{*}{$\begin{array}{l}\text { HH has } \\
\text { television }\end{array}$} & $-0.139^{\star \star}$ & $-0.076^{\star \star \star}$ & 0.034 & $0.101^{*}$ \\
\hline & $(0.047)$ & $(0.022)$ & $(0.030)$ & $(0.040)$ \\
\hline \multirow{2}{*}{$\begin{array}{l}\mathrm{HH} \text { has } \\
\text { refrigerator }\end{array}$} & -0.000 & -0.000 & 0.066 & 0.009 \\
\hline & $(0.067)$ & $(0.029)$ & $(0.039)$ & $(0.060)$ \\
\hline \multirow{2}{*}{$\begin{array}{l}\text { log monthly } \\
\text { earnings }\end{array}$} & $0.007^{*}$ & -0.001 & 0.003 & 0.004 \\
\hline & $(0.003)$ & $(0.002)$ & $(0.002)$ & $(0.003)$ \\
\hline \multirow[t]{2}{*}{ form } & $-0.438^{* \star *}$ & $-0.121^{\star * *}$ & 0.031 & $0.099^{\star *}$ \\
\hline & $(0.036)$ & $(0.017)$ & $(0.024)$ & $(0.031)$ \\
\hline \multirow[t]{2}{*}{ tertiary } & $-1.369^{* \star *}$ & $-0.195^{\star * *}$ & 0.005 & 0.113 \\
\hline & $(0.257)$ & $(0.051)$ & $(0.079)$ & $(0.085)$ \\
\hline N. & 1,343 & 1,341 & 1,189 & 1,343 \\
\hline
\end{tabular}

Note: Dependent variable: children ever born (column 1), ideal family size (column 2), contraception (columns 3-4). All variables described in Table1. Reference group with respect to education: primary school. Heteroskedasticityrobust standard errors reported in parentheses. Columns 1-2: Poisson model. Columns 3-4: probit (marginal effects). ${ }^{*} p<0.05,{ }^{* *} p<0.01,{ }^{* * *} p<0.001$.

Source: TLT-1 waves $1-8$. 
Table 5: Associations between mobile phone use and fertility-related outcomes among phone-owning women: 2015 cross-section

\begin{tabular}{|c|c|c|c|c|c|c|}
\hline & (1) & (2) & (3) & (4) & (5) & (6) \\
\hline & \multicolumn{6}{|c|}{ 1: \# of living children } \\
\hline mob. phone: mobile money & $\begin{array}{r}-0.161^{\star \star} \\
(0.060)\end{array}$ & & & & & \\
\hline mob. phone: internet & & $\begin{array}{r}-0.154^{*} \\
(0.069)\end{array}$ & & & & \\
\hline \multirow[t]{2}{*}{ mob. phone: SNs } & & & -0.156 & & & \\
\hline & & & $(0.094)$ & & & \\
\hline \multirow[t]{2}{*}{ mob. phone: business } & & & & -0.334 & & \\
\hline & & & & $(0.352)$ & & \\
\hline \multirow[t]{2}{*}{ mob. phone: call } & & & & & -0.150 & \\
\hline & & & & & $(0.117)$ & \\
\hline \multirow[t]{3}{*}{ mob. phone: video } & & & & & & -0.077 \\
\hline & & & & & & $(0.048)$ \\
\hline & & & Desirec & hildren & & \\
\hline \multirow[t]{2}{*}{ mob. phone: mobile money } & -0.044 & & & & & \\
\hline & $(0.023)$ & & & & & \\
\hline \multirow[t]{2}{*}{ mob. phone: internet } & & $-0.078^{\star *}$ & & & & \\
\hline & & $(0.026)$ & & & & \\
\hline \multirow[t]{2}{*}{ mob. phone: SNs } & & & -0.019 & & & \\
\hline & & & $(0.037)$ & & & \\
\hline \multirow[t]{2}{*}{ mob. phone: business } & & & & 0.027 & & \\
\hline & & & & $(0.093)$ & & \\
\hline \multirow[t]{2}{*}{ mob. phone: call } & & & & & 0.043 & \\
\hline & & & & & $(0.049)$ & \\
\hline \multirow[t]{2}{*}{ mob. phone: video } & & & & & & -0.011 \\
\hline & & & & & & $(0.021)$ \\
\hline \multirow{3}{*}{ mob. phone: mobile money } & & 3: Cont & eption: & mod. $\mathrm{m}$ & lods & \\
\hline & -0.029 & & & & & \\
\hline & $(0.033)$ & & & & & \\
\hline \multirow[t]{2}{*}{ mob. phone: internet } & & 0.047 & & & & \\
\hline & & $(0.035)$ & & & & \\
\hline \multirow[t]{2}{*}{ mob. phone: SNs } & & & 0.036 & & & \\
\hline & & & $(0.048)$ & & & \\
\hline \multirow[t]{2}{*}{ mob. phone: call } & & & & & -0.124 & \\
\hline & & & & & (0.093) & \\
\hline \multirow[t]{2}{*}{ mob. phone: video } & & & & & & -0.019 \\
\hline & & & & & & $(0.028)$ \\
\hline
\end{tabular}


Billari, Rotondi \& Trinitapoli: Mobile phones, digital inequality, and fertility

\section{Table 5: $\quad$ (Continued)}

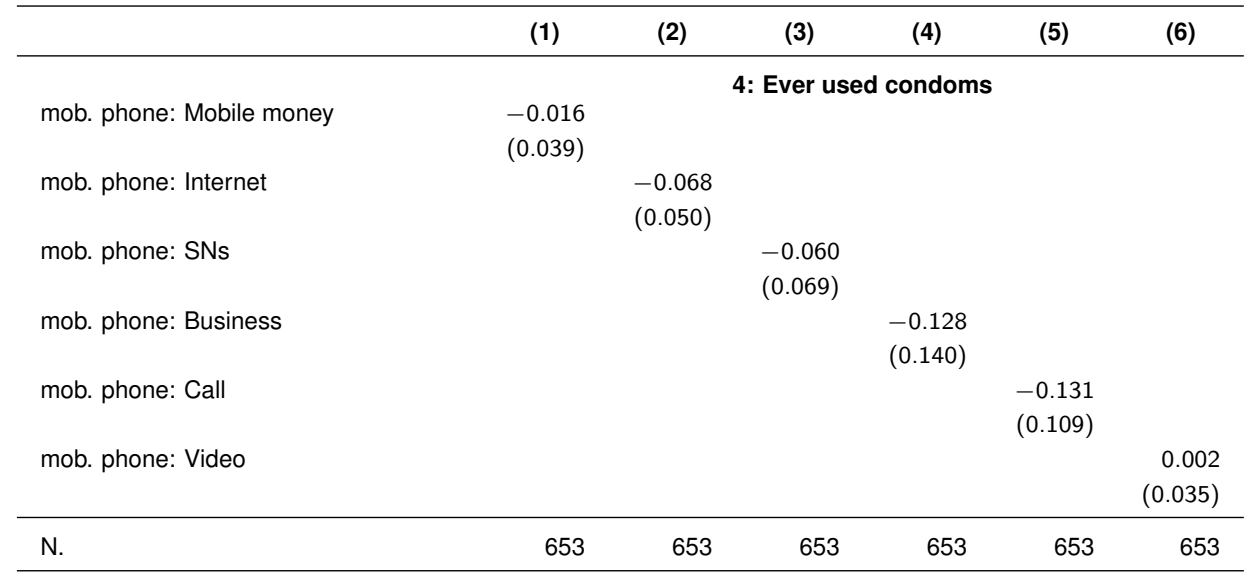

Note: All variables described in Table1. Heteroskedasticity-robust standard errors reported in parentheses. Panels 1-2: Poisson model. Panels 3-4: probit (marginal effects). Covariates used in the models: (log) monthly earnings, age, $\mathrm{HH}$ has television, $\mathrm{HH}$ has refrigerator, education, marital status. ${ }^{*} \mathrm{p}<0.05,{ }^{* *} \mathrm{p}<0.01,{ }^{* *} \mathrm{p}<0.001$. Source: TLT-2, 2015. 
The first line of Table 4 shows again, and not surprisingly, that mobile phone ownership is negatively associated with women's fertility preferences and parity - even in the cross section. The size of the coefficient is comparable to that of television ownership. However, no effect is found for uptake of modern contraception.

Table 5 analyzes differences in preferences, parity, and contraceptive use within the subset of mobile phone owners to identify variation by type of use. Among the phoneowning population, women who use phones to access the internet (as a proxy for access to information) and to use mobile money state a smaller IFS than do their counterparts who own phones but do not use them for this purpose. Internet-using women also have fewer children. From these analyses we cannot identify a true mechanism, but we interpret this evidence as tentative support for two of the four possible pathways we outlined at the outset: information access and preference change. Indeed, it appears that typical uses of a mobile phone (i.e., simply making calls, having conversations with family and friends) have no significant relationship to either dimension of fertility. Conversely, phone use geared toward gathering information may have a distinct set of implications for the fertility transition.

The negative correlation between mobile money and parity operates independently of socioeconomic status (i.e., money itself) and, in our view, merits particular consideration in future research. Although we would not read this finding as evidence that mobile money causes a change in fertility via preferences, we can think of several possible interpretations. Women's use of mobile money may index an efficacy or skill set that is also associated with the capacity to enact preferences for smaller families. Mobile money could, for example, facilitate access to remittances to better manage associated costs, including transportation.

\section{Discussion and conclusions}

In this paper, we established a negative relationship between mobile phone ownership and fertility among young adult women in a high-fertility African setting. In a nutshell, our results suggest that the digital revolution is contributing to the fertility patterns that characterize southern Malawi today. Although we don't go so far as to interpret the relationships as causal, the associations we estimate between mobile phones - ownership, acquisition, and use - and fertility are robust to an extensive set of controls, suggesting that phone ownership may not be entirely reducible to a single "new" dimension of socioeconomic status.

Our findings suggest that technology's contribution to fertility decline operates through mechanisms like role modeling, preference change, and access to information rather than through substitution effects. Furthermore, although none of the proximate determinants included in the analysis explain the relationship between mobile phone ownership and 
fertility (preferences or outcomes), we find that women with cell phones were less likely to experience a second birth during the study period. This finding is consistent with a model of preference change and with the literature on the importance of child spacing and postponement for understanding fertility patterns in sub-Saharan Africa.

This article focuses on fertility, a previously unexplored topic in the growing literature on the effect of mobile phones on health and development worldwide. Decades ago, scholars established that mass media shapes fertility preferences and outcomes in both developing and industrialized contexts (La Ferrara, Chong, and Duryea 2012; Kearney and Levine 2015; Trudeau 2016), but researchers have only now begun to examine the world's most widespread ICT's relationship to the reproductive realm. Our results point in the same direction as our antecedents in the literature on modernization and fertility, but the particular features of the devices and the context lead us to interpret our results from the TLT study in slightly different light.

Mobile phones have become a crucial medium for the spread of information and services, and this may be particularly true in rural and remote areas. Farmers use mobile phones to get information on the price of crops and livestock; rural households can receive remittances from relatives living in urban areas or pay school fees through mobile money services; and medical centers and NGOs can send text messages to their patients to remind them to take their medicines (Aker and Mbiti 2010). All these activities might have positive effects on women's ability to achieve their reproductive goals.

That mobile phones are two-way media makes the social implications of this technology qualitatively different from previous expansions of one-way mass media, such as radio and television (DiMaggio et al. 2001). Unlike the unified messages about family planning spread programmatically through radio programs and soap operas, information gathered from mobile phones or the internet is customizable and, by design, selectable. When surfing the net or collecting information through SMS, people are engaging in personalized searching strategies. This can result in the accumulation of tailored, accurate information (e.g., the best location to access contraception), but these same processes can also limit information and spread misinformation (i.e., rumors and fake news).

Lest our description of "information provision" come across as overly sunny, it would be naive to characterize the diffusion of information relevant to reproductive health as uniformly positive, and this issue merits serious study in its own right. At the darkest end of the spectrum, women attempting to gather information about family planning may encounter material that impedes their goals (e.g., by planting new concerns about mythical side effects). Moreover, if people use mobile phones to self-select content based on preexisting preferences and beliefs, the information gathered may be overwhelmingly redundant. Mobile phones can connect individuals to a wider social network, but they can also be a source of endogenous network formation in which individuals self-select according to their preferences. Although the literature depicts mobile phones as a tool 
that generates exchange, we do not see this exchange as "dialogue" but as a clustering of relevant and quasi-relevant opinions, as well as pieces of information and misinformation.

The lessons from TLT lead us to think that mobile phone use in Balaka may be empowering women, at least in the domain of their reproductive health and goals. One distinction from earlier media is that the information people receive through mobile phones can easily be kept private. For example, women can receive messages about contraceptives through their mobile phones (McCarthy et al. 2018) and decide to keep this information from their parents, partners, and friends. Our finding that mobile phone ownership patterns the interval between first and second birth, but not the patterning of first birth or marriage, suggests that the kind of "empowerment" going on in Malawi may be particular to women who have already met a set of social expectations - marriage and at least one child. Digital technologies may not convey the same kinds of benefits to adolescents or to adult women who have not yet fulfilled these social roles. Here, again, we believe more research is needed, and we point to the confluence of women's autonomy, contraceptive access, and fertility behaviors as a particularly important channel to follow as research on the digitization of social life evolves.

Given the strength, magnitude, and consistency of the relationship between mobile phones and fertility for young women in Balaka, we recommend that scholars engaged in data collection efforts focused on fertility, contraceptive use, reproductive health, and other demographic phenomena begin to expand their notion of socioeconomic status to include mobile phones. Only a few studies have begun to gather such information, but the added costs of doing so are low, and the value of adding measures of digital engagement would be hard to overstate. More detailed data on amount and type of use will be especially beneficial as ownership expands to a point of near-saturation - even in poor countries.

As ICTs expand and become more powerful, the digital revolution will have multiplex implications for inequality - implications that demographers are uniquely positioned to engage, advance, and understand. As barriers to access decline, new inequalities - a second-level digital divide - will inevitably emerge. Unlike patterns of access, which are relatively simple to assess, we expect that these new inequalities will be rooted in differences in the use of digital tools like mobile phones and personal computers and will be more difficult to unpack analytically. Digital technologies may be empowering many women and men who have gained access, but others will lag behind, exacerbating the digital divide within and across countries. We expect that as demographic transformations and the digital revolution play out in the long run, digital technologies will play an increasingly central role in our understandings of ideational change and shifts in related demographic behaviors. This study of mobile phones and fertility is among the first to explicitly move the field in such a direction. 


\section{Acknowledgments}

This project has received funding from the European Research Council (ERC) under the European Union's Horizon 2020 Research and Innovation programme (grant agreement no. 694262), project DisCont - Discontinuities in Household and Family Formation. This research uses data from Tsogolo la Thanzi, a research project designed by Jenny Trinitapoli and Sara Yeatman, funded by grants R01-HD058366 and R01-HD077873 from the National Institute of Child Health and Human Development. TLT data are available through restricted data-user agreements managed by Data Sharing for Demographic Research (DSDR) at the University of Michigan. We are grateful to Nicoletta Balbo, Ann Biddlecom, Vincenz Frey, Simone Ghislandi, Ridhi Kashyap, Alessandro di Nallo, Luca M. Pesando, Rebecca Graziani, Luca Stella, and three anonymous reviewers for their comments and suggestions. 


\section{References}

Aker, J.C. (2010). Information from markets near and far: Mobile phones and agricultural markets in Niger. American Economic Journal: Applied Economics 2(3): 46-59. doi:10.1257/app.2.3.46.

Aker, J.C. and Fafchamps, M. (2014). Mobile phone coverage and producer markets: Evidence from West Africa. The World Bank Economic Review 29(2): 262-292. doi:10.1093/wber/lhu006.

Aker, J.C., Ksoll, C., and Lybbert, T.J. (2012). Can mobile phones improve learning? Evidence from a field experiment in Niger. American Economic Journal: Applied Economics 4(4): 94-120. doi:10.1257/app.4.4.94.

Aker, J.C. and Mbiti, I.M. (2010). Mobile phones and economic development in Africa. The Journal of Economic Perspectives 24(3): 207-232. doi:10.1257/jep.24.3.207.

Allison, P.D. (2005). Fixed effects regression methods for longitudinal data using SAS. Cary: SAS Institute.

Allison, P.D. (2009). Fixed effects regression models, vol. 160. Thousand Oaks: SAGE publications. doi:10.4135/9781412993869.

Allison, P.D. and Waterman, R.P. (2002). Fixed-effects negative binomial regression models. Sociological methodology 32(1): 247-265. doi:10.1111/1467-9531.00117.

Bachan, L.K. (2014). Anticipatory child fostering and household economic security in Malawi. Demographic research 30: 1157. doi:10.4054/DemRes.2014.30.40.

Behrman, J.R., Kohler, H.P., and Watkins, S.C. (2002). Social networks and changes in contraceptive use over time: Evidence from a longitudinal study in rural Kenya. Demography 39(4): 713-738. doi:10.1353/dem.2002.0033.

Blauw, S. and Franses, P.H. (2016). Off the hook: Measuring the impact of mobile telephone use on economic development of households in Uganda using copulas. The Journal of Development Studies 52(3): 315-330. doi:10.1080/00220388.2015.1056783.

Bongaarts, J. (2017). Africa's unique fertility transition. Population and Development Review 43(S1): 39-58. doi:10.1111/j.1728-4457.2016.00164.x.

Bongaarts, J. and Watkins, S.C. (1996). Social interactions and contemporary fertility transitions. Population and Development Review 639-682. doi:10.2307/2137804.

Bongaarts, J. et al. (1978). A framework for analyzing the proximate determinants of fertility. Population and development review 4(1): 105-132. doi:10.2307/1972149.

Buys, P., Dasgupta, S., Thomas, T.S., and Wheeler, D. (2009). Determinants of a digital 
divide in Sub-Saharan Africa: A spatial econometric analysis of cell phone coverage. World Development 37(9): 1494-1505. doi:10.1016/j.worlddev.2009.01.011.

Cox, D.R. (1972). Regression models and life-tables. Journal of the Royal Statistical Society: Series B (Methodological) 34(2): 187-202. doi:10.1111/j.25176161.1972.tb00899.x.

Della Vigna, S. and La Ferrara, E. (2015). Economic and social impacts of the media. In: Anderson, S., Waldfogel, J., and Stromberg, D. (eds.). Handbook of media economics: $1 A$ and $1 B$. North Holland.

Dillon, A. (2013). Child labour and schooling responses to production and health shocks in northern Mali. Journal of African Economies 22(2): 276-299. doi:10.1093/jae/ejs025.

DiMaggio, P., Hargittai, E., Neuman, W.R., and Robinson, J.P. (2001). Social implications of the Internet. Annual Review of Sociology 27(1): 307-336. doi:10.1146/annurev.soc.27.1.307.

Faria, V.E. and Potter, J.E. (1999). 11 television, telenovelas, and fertility change in North-East Brazil. In: Leete, R. (ed.). Dynamics of values in fertility change. Oxford: Clarendon Press: 252.

Hargittai, E. (2002). Second-level digital divide: Differences in people's online skills. First Monday 7(4). doi:10.5210/fm.v7i4.942.

Hübler, M. and Hartje, R. (2016). Are smartphones smart for economic development? Economics Letters 141: 130-133. doi:10.1016/j.econlet.2016.02.001.

ITU (2010). Information society statistical profiles 2009, Africa. Geneva: International Telecommunications Union.

ITU (2014). Measuring the information - Society report 2014. Geneva: International Telecommunication Union.

Jack, W. and Suri, T. (2014). Risk sharing and transactions costs: Evidence from Kenya's mobile money revolution. American Economic Review 104(1): 183-223. doi:10.1257/aer.104.1.183.

Jensen, R. (2007). The digital provide: Information (technology), market performance, and welfare in the South Indian fisheries sector. The Quarterly Journal of Economics 122(3): 879-924. doi:10.1162/qjec.122.3.879.

Johnson-Hanks, J. (2004). Uncertainty and the second space: Modern birth timing and the dilemma of education. European Journal of Population / Revue Europeenne de Demographie 20(4): 351. doi:10.1007/s10680-004-4095-5. 
Kearney, M.S. and Levine, P.B. (2015). Media influences on social outcomes: The impact of MTV's 16 and pregnant on teen childbearing. American Economic Review 105(12): 3597-3632. doi:10.1257/aer.20140012.

Kohler, H.P., Behrman, J.R., and Watkins, S.C. (2001). The density of social networks and fertility decisions: Evidence from South Nyanza District, Kenya. Demography 38(1): 43-58. doi:10.1353/dem.2001.0005.

La Ferrara, E. (2016). Mass media and social change: Can we use television to fight poverty? Journal of the European Economic Association 14(4): 791-827. doi:10.1111/jeea.12181.

La Ferrara, E., Chong, A., and Duryea, S. (2012). Soap operas and fertility: Evidence from Brazil. American Economic Journal: Applied Economics 4(4): 1-31. doi:10.1257/app.4.4.1.

Lester, R.T., Ritvo, P., Mills, E.J., Kariri, A., Karanja, S., Chung, M.H., Jack, W., Habyarimana, J., Sadatsafavi, M., Najafzadeh, M. et al. (2010). Effects of a mobile phone short message service on antiretroviral treatment adherence in Kenya ('WelTel Kenya1'): A randomised trial. The Lancet 376(9755): 1838-1845. doi:10.1016/S01406736(10)61997-6.

Manacorda, M. and Tesei, A. (2020). Liberation technology: Mobile phones and political mobilization in Africa. Econometrica 88(2): 533-567. doi:10.3982/ECTA14392.

McCarthy, O.L., Wazwaz, O., Calderon, V.O., Jado, I., Saibov, S., Stavridis, A., Gallardo, J.L., Tokhirov, R., Adada, S., Huaynoca, S. et al. (2018). Development of an intervention delivered by mobile phone aimed at decreasing unintended pregnancy among young people in three lower middle income countries. BMC public health 18(1): 576. doi:10.1186/s12889-018-5477-7.

McDaniel, B.T. and Coyne, S.M. (2016). Technoference: The interference of technology in couple relationships and implications for women's personal and relational wellbeing. Psychology of Popular Media Culture 5(1): 85. doi:10.1037/ppm0000065.

Melkersson, M. and Rooth, D.O. (2000). Modeling female fertility using inflated count data models. Journal of Population Economics 13(2): 189-203. doi:10.1007/s001480050133.

Miller-Ott, A.E., Kelly, L., and Duran, R.L. (2012). The effects of cell phone usage rules on satisfaction in romantic relationships. Communication Quarterly 60(1): 17-34. doi:10.1080/01463373.2012.642263.

Mitullah, W.V., Samson, R., Wambua, P.M., and Balongo, S. (2016). AD69: Building on progress: Infrastructure development still a major challenge in Africa. Accra: Afrobarometer (Dispatch 69). 
Montgomery, M.R. and Casterline, J.B. (1996). Social learning, social influence, and new models of fertility. Population and Development Review 22: 151-175. doi: $10.2307 / 2808010$.

Munyegera, G.K. and Matsumoto, T. (2016). Mobile money, remittances, and household welfare: Panel evidence from rural Uganda. World Development 79: 127-137. doi:10.1016/j.worlddev.2015.11.006.

Murendo, C. and Wollni, M. (2016). Mobile money and household food security in Uganda. Göttingen: Georg-August-Universität Göttingen (GlobalFood Discussion Paper 858-2016-60328).

Norris, P. (2001). Digital divide: Civic engagement, information poverty, and the Internet worldwide. Cambridge: Cambridge University Press. doi:10.1017/CBO9781139164887.

NSO and ICF (2011). Malawi demographic and health survey report 2010. Zomba: National Statistical Office [of Malawi]; Rockville: ICF.

NSO and ICF (2017). Malawi demographic and health survey report 2015-2016. Zomba: National Statistical Office [of Malawi]; Rockville: ICF.

Paz Soldan, V.A. (2004). How family planning ideas are spread within social groups in rural Malawi. Studies in family planning 35(4): 275-290. doi:10.1111/j.00393665.2004.00031.x.

Perumean-Chaney, S.E., Morgan, C., McDowall, D., and Aban, I. (2013). Zero-inflated and overdispersed: What's one to do? Journal of Statistical Computation and Simulation 83(9): 1671-1683. doi:10.1080/00949655.2012.668550.

Rosenfeld, M.J. and Thomas, R.J. (2012). Searching for a mate: The rise of the Internet as a social intermediary. American Sociological Review 77(4): 523-547. doi:10.1177/0003122412448050.

Rotondi, V., Stanca, L., and Tomasuolo, M. (2017). Connecting alone: Smartphone use, quality of social interactions and well-being. Journal of Economic Psychology 63(2017): 17-26. doi:10.1016/j.joep.2017.09.001.

Roycroft, T.R. and Anantho, S. (2003). Internet subscription in Africa: Policy for a dual digital divide. Telecommunications Policy 27(1): 61-74. doi:10.1016/S03085961(02)00091-5. Telecommunications in Africa.

Suri, T. and Jack, W. (2016). The long-run poverty and gender impacts of mobile money. Science 354(6317): 1288-1292. doi:10.1126/science.aah5309.

Thornton, A. (2001). The developmental paradigm, reading history sideways, and family change. Demography 38(4): 449-465. doi:10.1353/dem.2001.0039. 
Timæus, I.M. and Moultrie, T.A. (2008). On postponement and birth intervals. Population and Development Review 34(3): 483-510. doi:10.1111/j.1728-4457.2008.00233.x.

Trudeau, J. (2016). The role of new media on teen sexual behaviors and fertility outcomes - the case of 16 and pregnant. Southern Economic Journal 82(3): 975-1003. doi:10.1002/soej.12034.

Zereyesus, Y.A., Embaye, W.T., Tsiboe, F., and Amanor-Boadu, V. (2017). Implications of non-farm work to vulnerability to food poverty-recent evidence from northern Ghana. World Development 91: 113-124. doi:10.1016/j.worlddev.2016.10.015.

Zurovac, D., Sudoi, R.K., Akhwale, W.S., Ndiritu, M., Hamer, D.H., Rowe, A.K., and Snow, R.W. (2011). The effect of mobile phone text-message reminders on Kenyan health workers' adherence to Malaria treatment guidelines: A cluster randomised trial. The Lancet 378(9793): 795-803. doi:10.1016/S0140-6736(11)60783-6. 


\title{
Appendix: Additional figures and tables
}

\section{Figure A-1: $\quad$ Distribution of education at wave 1}

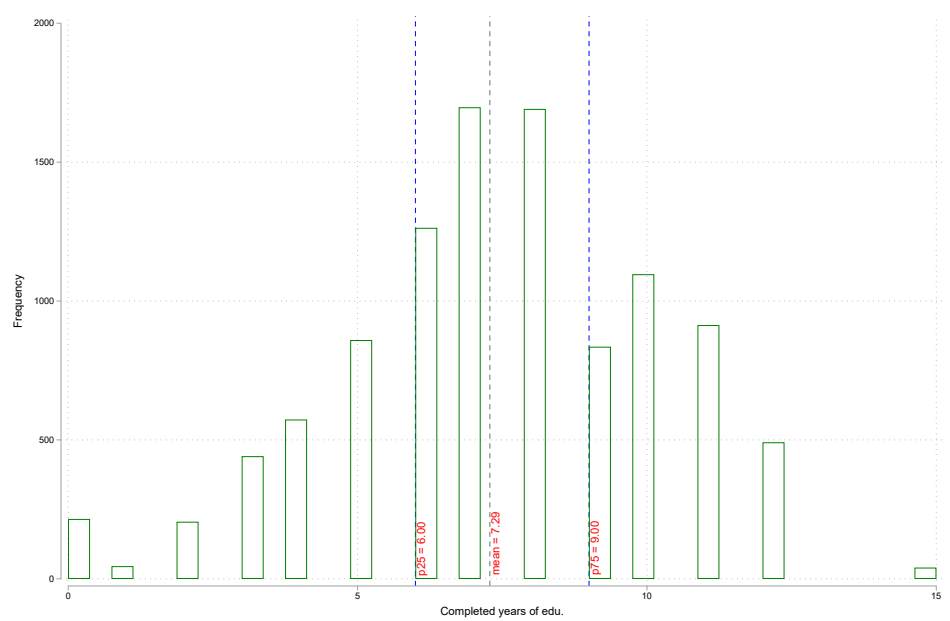

\begin{abstract}
Attrition
The original TLT sample (2009) is comprised of 1,505 women; $72 \%$ of them were interviewed eight times and $76 \%$ of them were interviewed seven times. To understand how attrition might bias our estimates, we inspect whether attrition is related to mobile phone ownership. We therefore build two dummy variables. The first one (attrited1) takes value 1 if the women is not interviewed in wave 2 and takes value 0 otherwise. The second one (attrited6) takes value 1 if the woman is not interviewed in wave 7 and takes value 0 otherwise. We then regress those two dummies on mobile phone ownership at time t-1 while controlling for the same set of covariates used along the empirical analysis. Reassuringly, results in Table A-1 show that the probability of attrition is not related to mobile phone ownership. Based on this finding, it seems unlikely that selection bias is driving the results of the analysis. However, when comparing the missing women with those remaining in the sample, we realize that women who abandoned the panel were both wealthier and older at baseline. Since mobile phone ownership is positively related to wealth, our estimate of the effect of mobile phone ownership on parity should be an upper bound of the true effect.
\end{abstract}




\section{Table A-1: $\quad$ Attrition}

\begin{tabular}{lcc}
\hline & $\begin{array}{c}(\mathbf{1}) \\
\text { attrited1 }\end{array}$ & $\begin{array}{c}(\mathbf{2}) \\
\text { attrited6 }\end{array}$ \\
\hline owns mobile & 0.0005 & 0.0038 \\
phone (t-1) & $(0.0014)$ & $(0.0022)$ \\
monthly earnings & -0.0000 & 0.0001 \\
(in Malawian & & \\
kwacha, log) & $(0.0002)$ & $(0.0002)$ \\
age (in months) & $-0.0000^{\star *}$ & 0.0000 \\
HH has television & $(0.0000)$ & $(0.0000)$ \\
HH has & 0.0039 & $0.0079^{\star}$ \\
refrigerator & $(0.0028)$ & $(0.0039)$ \\
& 0.0065 & 0.0024 \\
$\mathrm{~N}$. & $(0.0045)$ & $(0.0036)$ \\
\hline
\end{tabular}

Note: All variables described in Table 1. Probit (marginal effects). ${ }^{*} p<0.05,{ }^{* *} p<0.01,{ }^{* * *} p<0.001$. 
Billari, Rotondi \& Trinitapoli: Mobile phones, digital inequality, and fertility

\section{Poisson model}

Table A-2: $\quad$ Effects of mobile phone use on fertility: Poisson model

\begin{tabular}{|c|c|c|c|c|c|c|}
\hline & $\begin{array}{c}\text { Main } \\
(1)\end{array}$ & $\begin{array}{l}\text { Preferences } \\
\text { (2) }\end{array}$ & $\begin{array}{l}\text { Proximate } \\
\text { (3) }\end{array}$ & $\begin{array}{l}\text { eterminants } \\
\text { (4) }\end{array}$ & $\begin{array}{r}\text { fertility } \\
(5)\end{array}$ & $\begin{array}{l}\text { All } \\
(6)\end{array}$ \\
\hline \multirow{3}{*}{$\begin{array}{l}\text { Random- } \\
\text { effects } \\
\text { owns mobile } \\
\text { phone }(t-3)\end{array}$} & & & & & & \\
\hline & $-0.1214^{\star * *}$ & $-0.1103^{\star * *}$ & $-0.1185^{\star * *}$ & $-0.1048^{\star \star \star}$ & $-0.1207^{\star \star \star}$ & $-0.0900^{* *}$ \\
\hline & $(0.0309)$ & $(0.0287)$ & $(0.0307)$ & $(0.0312)$ & $(0.0309)$ & $(0.0291)$ \\
\hline \multicolumn{7}{|l|}{$\begin{array}{l}\text { Population } \\
\text { averaged } \\
\text { (PA) }\end{array}$} \\
\hline \multirow{2}{*}{$\begin{array}{l}\text { owns mobile } \\
\text { phone }(t-3)\end{array}$} & $-0.0402^{\star \star *}$ & $-0.0397^{* * *}$ & $-0.0389^{\star \star}$ & $-0.0374^{\star *}$ & $-0.0397^{\star \star \star}$ & $-0.0361^{* *}$ \\
\hline & $(0.0118)$ & $(0.0118)$ & $(0.0118)$ & $(0.0119)$ & (0.0117) & $(0.0117)$ \\
\hline N. & 6182 & 6177 & 6182 & 6182 & 6182 & 6177 \\
\hline \multicolumn{7}{|l|}{$\begin{array}{l}\text { Fixed- } \\
\text { effects }\end{array}$} \\
\hline \multirow{2}{*}{$\begin{array}{l}\text { owns mobile } \\
\text { phone }(t-3)\end{array}$} & -0.0075 & -0.0075 & -0.0070 & -0.0063 & -0.0076 & -0.0062 \\
\hline & $(0.0477)$ & $(0.0477)$ & $(0.0477)$ & $(0.0477)$ & $(0.0477)$ & $(0.0477)$ \\
\hline $\mathrm{N}$. & 4168 & 4165 & 4168 & 4168 & 4168 & 4165 \\
\hline \multicolumn{7}{|l|}{$\begin{array}{l}\text { Hybrid } \\
\text { zero-inflated } \\
\text { Poisson }\end{array}$} \\
\hline \multirow{2}{*}{$\begin{array}{l}\text { owns mobile } \\
\text { phone }(t-3)\end{array}$} & $-0.2657^{\star \star \star}$ & $-0.1889^{* \star *}$ & $-0.2429^{\star \star \star}$ & $-0.1651^{\star \star \star}$ & $-0.2677^{\star \star \star}$ & $-0.1119^{\star * *}$ \\
\hline & $(0.0286)$ & (0.0289) & $(0.0285)$ & $(0.0282)$ & $(0.0286)$ & $(0.0285)$ \\
\hline $\mathrm{N}$. & 6182 & 6177 & 6182 & 6182 & 6182 & 6177 \\
\hline
\end{tabular}

Note: All variables described in Table 1. Cluster-robust standard errors reported in parentheses. Poisson models. Different specifications. ${ }^{*} p<0.05,{ }^{* *} p<0.01,{ }^{* * *} p<0.001$. 


\section{Cox proportional hazard model}

Table A-3: $\quad$ Hazard rates by phone ownership

\begin{tabular}{lccc}
\hline & $\begin{array}{c}(\mathbf{1}) \\
\text { First marriage }\end{array}$ & $\begin{array}{c}(\mathbf{2}) \\
\text { First birth }\end{array}$ & $\begin{array}{c}\text { (3) } \\
\text { Second birth }\end{array}$ \\
\hline owns mobile phone & 1.0060 & $0.9319^{*}$ & $0.8653^{* * *}$ \\
standard controls & $(0.0309)$ & $(0.0298)$ & $(0.0345)$ \\
N. & yes & yes & yes \\
\hline
\end{tabular}

Note: All variables described in Table 1. Standard errors reported in brackets. Cox proportional hazard model. * $p$ $<0.05,{ }^{* *} p<0.01,{ }^{* * *} p<0.001$. 
Billari, Rotondi \& Trinitapoli: Mobile phones, digital inequality, and fertility

Further robustness checks

Table A-4: $\quad$ Effects of mobile phone on fertility: Further robustness checks

\begin{tabular}{|c|c|c|c|c|c|c|}
\hline & $\begin{array}{c}\text { Main } \\
(1)\end{array}$ & $\begin{array}{l}\text { Preferences } \\
\text { (2) }\end{array}$ & $\begin{array}{l}\text { Proximate } \\
\text { (3) }\end{array}$ & $\begin{array}{l}\text { leterminants } \\
\text { (4) }\end{array}$ & $\begin{array}{l}\text { of fertility } \\
\text { (5) }\end{array}$ & $\begin{array}{l}\text { All } \\
(6)\end{array}$ \\
\hline \multicolumn{7}{|l|}{$\begin{array}{l}\text { Panel A: No age (educ. in } \\
\text { months) }\end{array}$} \\
\hline owns mobile phone $(t-3)$ & $\begin{array}{r}-0.0353^{*} \\
(0.0146)\end{array}$ & $\begin{array}{r}-0.0354^{*} \\
(0.0146)\end{array}$ & $\begin{array}{r}-0.0348^{*} \\
(0.0146)\end{array}$ & $\begin{array}{r}-0.0355^{*} \\
(0.0145)\end{array}$ & $\begin{array}{r}-0.0349^{*} \\
(0.0142)\end{array}$ & $\begin{array}{r}-0.0350^{*} \\
(0.0142)\end{array}$ \\
\hline \multirow{2}{*}{$\begin{array}{l}\text { Panel B: Age and educ. } \\
\text { in years (random-effects) } \\
\text { owns mobile phone }(t-3)\end{array}$} & & & & & & \\
\hline & $\begin{array}{r}-0.0464^{* *} \\
(0.0144)\end{array}$ & $\begin{array}{r}-0.0462^{* *} \\
(0.0144)\end{array}$ & $\begin{array}{r}-0.0463^{\star *} \\
(0.0143)\end{array}$ & $\begin{array}{r}-0.0466^{* *} \\
(0.0142)\end{array}$ & $\begin{array}{r}-0.0461^{\star *} \\
(0.0141)\end{array}$ & $\begin{array}{r}-0.0453^{\star \star} \\
(0.0139)\end{array}$ \\
\hline \multicolumn{7}{|l|}{ Panel C: Wealth } \\
\hline owns mobile phone $(t-3)$ & $\begin{array}{r}-0.0354^{*} \\
(0.0146)\end{array}$ & $\begin{array}{r}-0.0355^{*} \\
(0.0146)\end{array}$ & $\begin{array}{r}-0.0350^{*} \\
(0.0145)\end{array}$ & $\begin{array}{r}-0.0358^{*} \\
(0.0145)\end{array}$ & $\begin{array}{r}-0.0348^{*} \\
(0.0142)\end{array}$ & $\begin{array}{r}-0.0351^{\star} \\
(0.0141)\end{array}$ \\
\hline \multirow{2}{*}{$\begin{array}{l}\text { monthly earnings (in } \\
\text { Malawian kwacha, } \log \text { ) }\end{array}$} & -0.0021 & -0.0021 & -0.0021 & -0.0025 & -0.0023 & $-0.0028^{*}$ \\
\hline & $(0.0014)$ & $(0.0013)$ & $(0.0014)$ & $(0.0013)$ & $(0.0013)$ & $(0.0013)$ \\
\hline \multirow[t]{2}{*}{ age (in months) } & $0.0201^{* * *}$ & $0.0201^{\star \star \star}$ & $0.0199^{\star \star *}$ & $0.0195^{\star \star \star}$ & $0.0205^{\star \star \star}$ & $0.0199^{\star \star \star}$ \\
\hline & $(0.0010)$ & $(0.0010)$ & $(0.0010)$ & $(0.0010)$ & $(0.0010)$ & $(0.0010)$ \\
\hline \multirow[t]{2}{*}{$\mathrm{HH}$ has television } & -0.0069 & -0.0071 & -0.0084 & -0.0093 & -0.0101 & -0.0131 \\
\hline & $(0.0173)$ & $(0.0173)$ & $(0.0173)$ & $(0.0175)$ & $(0.0173)$ & $(0.0175)$ \\
\hline \multirow[t]{2}{*}{$\mathrm{HH}$ has refrigerator } & 0.0195 & 0.0199 & 0.0213 & 0.0208 & 0.0288 & 0.0309 \\
\hline & $(0.0278)$ & $(0.0277)$ & $(0.0277)$ & $(0.0275)$ & $(0.0284)$ & $(0.0280)$ \\
\hline has electricity & $\begin{array}{r}-0.0584^{* *} \\
(0.0226)\end{array}$ & $\begin{array}{r}-0.0585^{* *} \\
(0.0226)\end{array}$ & $\begin{array}{r}-0.0586^{* *} \\
(0.0225)\end{array}$ & $\begin{array}{r}-0.0582^{* *} \\
(0.0221)\end{array}$ & $\begin{array}{r}-0.0586^{* *} \\
(0.0219)\end{array}$ & $\begin{array}{r}-0.0586^{* *} \\
(0.0214)\end{array}$ \\
\hline \multirow[t]{2}{*}{ wood/bamboo } & $0.0861^{\star \star \star}$ & $0.0859^{\star \star *}$ & $0.0859^{\star \star \star}$ & $0.0799^{\star * *}$ & $0.1108^{\star \star *}$ & $0.1048^{\star \star \star}$ \\
\hline & $(0.0102)$ & $(0.0102)$ & $(0.0102)$ & $(0.0101)$ & $(0.0106)$ & $(0.0106)$ \\
\hline \multirow[t]{2}{*}{ cement } & -0.0003 & -0.0008 & -0.0005 & 0.0013 & -0.0049 & -0.0042 \\
\hline & $(0.0207)$ & $(0.0207)$ & $(0.0206)$ & $(0.0202)$ & $(0.0204)$ & $(0.0199)$ \\
\hline \multirow[t]{2}{*}{ tiles } & $0.1730^{\star \star \star}$ & $0.1730^{\star \star \star}$ & $0.1718^{\star \star \star *}$ & $0.1717^{\star \star \star}$ & $0.1730^{\star \star \star}$ & $0.1711^{\star \star \star}$ \\
\hline & $(0.0376)$ & $(0.0376)$ & $(0.0375)$ & $(0.0356)$ & $(0.0376)$ & $(0.0356)$ \\
\hline \multirow[t]{2}{*}{ bricks } & 0.0284 & 0.0279 & 0.0269 & 0.0186 & 0.0428 & 0.0328 \\
\hline & $(0.0797)$ & $(0.0797)$ & $(0.0803)$ & $(0.0767)$ & $(0.0790)$ & $(0.0767)$ \\
\hline
\end{tabular}


Table A-4: $\quad$ (Continued)

\begin{tabular}{|c|c|c|c|c|c|c|}
\hline & $\begin{array}{l}\text { Main } \\
(1)\end{array}$ & $\begin{array}{l}\text { Preferences } \\
\text { (2) }\end{array}$ & $\begin{array}{l}\text { Proximate } \\
\text { (3) }\end{array}$ & $\begin{array}{l}\text { eterminant } \\
\text { (4) }\end{array}$ & $\begin{array}{l}\text { f fertility } \\
\text { (5) }\end{array}$ & $\begin{array}{l}\text { All } \\
(6)\end{array}$ \\
\hline \multirow{3}{*}{$\begin{array}{l}\text { (continued) } \\
\text { Panel C: Wealth } \\
\text { no facility (bush, field, } \\
\text { bucket) }\end{array}$} & & & & & & \\
\hline & -0.0025 & -0.0008 & -0.0063 & -0.0079 & -0.0051 & -0.0102 \\
\hline & $(0.0511)$ & $(0.0512)$ & $(0.0511)$ & $(0.0506)$ & $(0.0496)$ & $(0.0493)$ \\
\hline \multirow{2}{*}{$\begin{array}{l}\text { traditional pit latrine (mud, } \\
\text { thatch) }\end{array}$} & -0.0191 & -0.0195 & -0.0212 & -0.0260 & -0.0261 & -0.0336 \\
\hline & $(0.0338)$ & $(0.0338)$ & $(0.0338)$ & $(0.0335)$ & $(0.0325)$ & $(0.0321)$ \\
\hline \multirow{2}{*}{$\begin{array}{l}\text { improved pit latrine } \\
\text { (cement) }\end{array}$} & -0.0198 & -0.0199 & -0.0208 & -0.0246 & -0.0281 & -0.0330 \\
\hline & $(0.0292)$ & $(0.0292)$ & $(0.0293)$ & $(0.0292)$ & $(0.0283)$ & $(0.0282)$ \\
\hline \multirow[t]{2}{*}{ grass thatched } & -0.0069 & -0.0071 & -0.0079 & -0.0087 & -0.0085 & -0.0108 \\
\hline & $(0.0222)$ & $(0.0222)$ & $(0.0222)$ & $(0.0220)$ & $(0.0220)$ & $(0.0218)$ \\
\hline \multirow[t]{2}{*}{ asbestos } & -0.0298 & -0.0294 & -0.0278 & -0.0464 & -0.0061 & -0.0206 \\
\hline & $(0.0918)$ & $(0.0918)$ & $(0.0908)$ & $(0.0853)$ & $(0.0863)$ & $(0.0803)$ \\
\hline \multirow[t]{2}{*}{ cement } & -0.0600 & -0.0598 & -0.0631 & -0.0725 & -0.0479 & -0.0607 \\
\hline & $(0.0876)$ & $(0.0875)$ & $(0.0851)$ & $(0.0765)$ & $(0.0831)$ & $(0.0717)$ \\
\hline \multirow[t]{2}{*}{ has personal savings } & -0.0107 & -0.0103 & -0.0099 & -0.0093 & -0.0099 & -0.0081 \\
\hline & $(0.0123)$ & $(0.0123)$ & $(0.0123)$ & $(0.0122)$ & $(0.0121)$ & $(0.0120)$ \\
\hline standard controls & Yes & Yes & Yes & Yes & Yes & Yes \\
\hline \multicolumn{7}{|l|}{ Panel D: Wealth index } \\
\hline \multirow{2}{*}{ owns mobile phone $(t-3)$} & $-0.0350^{*}$ & $-0.0352^{*}$ & $-0.0346^{*}$ & $-0.0351^{*}$ & $-0.0347^{*}$ & $-0.0348^{*}$ \\
\hline & $(0.0146)$ & $(0.0146)$ & $(0.0146)$ & $(0.0146)$ & $(0.0143)$ & $(0.0142)$ \\
\hline \multirow[t]{2}{*}{$\mathrm{HH}$ wealth index } & -0.0042 & -0.0043 & -0.0037 & -0.0031 & -0.0053 & -0.0042 \\
\hline & $(0.0064)$ & $(0.0065)$ & $(0.0064)$ & $(0.0064)$ & $(0.0063)$ & $(0.0062)$ \\
\hline standard controls & Yes & Yes & Yes & Yes & Yes & Yes \\
\hline
\end{tabular}

Note: All variables described in Table 1. Coefficients derived from fixed-effects OLS models if not differently specified. Cluster-robust standard errors in parentheses. ${ }^{*} p<0.05,{ }^{* *} p<0.01,{ }^{* * *} p<0.001$. 
Billari, Rotondi \& Trinitapoli: Mobile phones, digital inequality, and fertility 